\title{
The effect of internationalization, industrial type, and company size on corporate social responsibility disclosure
}

\author{
Frista $^{1 *}$, Kenny Fernando ${ }^{2}$ \\ ${ }^{1}$ Department of Accounting, Faculty of Business, Universitas Kristen Duta Wacana, Yogyakarta, Indonesia \\ ${ }^{2}$ Department of Accounting, Faculty of Social, Podomoro University, Jakarta, Indonesia \\ *Corresponding author: frista@staff.ukdw.ac.id
}

\begin{abstract}
The Multinational Companies has been internationally connected to the world where transparency and accessible information about economic, social, and environment are ultimately required. This study aims to determine the factors that affect the level Corporate Social Responsibility Disclosure (CSRD) by examining the effect of internationalization, industry type, and company size. The samples used are manufacturing companies listed on the BEI during 2013-2015. Data obtained from the company's annual reports. This research uses a quantitative approach with multiple linear regression analysis. On the other side, the researchers also use internalization instead of foreign ownership which existing researches mostly use. In addition, it distinguishably uses NVIVO Software in measuring CSRD instead of scoring to decrease subjectivity. This study shows that the size of firm has a positive effect on the CSRD. There is no evidence of internationalization and industry type effect on the level of CSRD in Indonesia.
\end{abstract}

Keywords: CSR disclosure, internationalization

JEL Classification Code: M14

DOI: $10.20885 /$ jsb.vol24.iss2.art4

\section{Introduction}

Along with the increasingly open flow of information and capital in the world, the existence of Multinational Companies (MNC) is a common thing. Multinational companies exist in almost all parts of the world, including Indonesia. MNCs have a desire to expand their business by expanding markets and forming new business segments. For this reason, the company will invest capital by establishing branch companies, subsidiaries, or associated companies. Multinational companies will carry out international trade transactions with third parties and related parties abroad that involve themselves in new demands for increased transparency and across the nationalization of companies (John et al., 2013). When these companies are internationalized, they must be more responsive to social and environmental issues that are developing at this time. European countries and the United States are countries that are very concerned about social issues; such as human rights violations, education, labor and environmental issues such as the greenhouse effect, illegal logging, and water pollution (Cahyono, 2011). As such, MNCs should disclose social and environmental responsibilities in Corporate Social Responsibility Report beyond those which only operate locally. We found that in developed countries, CSRD has attracted the public attention. Nevertheless, the same disclosure in developing countries including Asian countries, specifically in Indonesia is considered low (Loh et al., 2016; Moon \& Chapple, 2005).

Recently the European Union Parliament issued a decision protesting by the Indonesian government regarding the resolution of oil palm and the banning of palm oil based biodiesel (Kompas, 2017). These sustainability issues are the basis for the decision issuance. The resolution was issued, because it was considered to still create many problems from deforestation, corruption, child labor, to human rights violations. The corporate social responsibility (CSR) is a concept that has attracted the world's attention and gained new significance in the global economy (John et al., 2013). This concept is disclosed in the CSR Report and the information is referred to CSR 
Disclosure (CSRD). We see based on the protesting phenomena creates barriers to international relation among companies across the nations. The international trade at this time is no longer solely based on tariffs but has extended to issues of sustainability (Akinyomi, 2013). This export restriction decision will certainly adversely affect the going concern of the company. In this case the affected company segment is the agricultural sector. However, it certainly does not rule out the possibility that other fields will be affected by this resolution policy. Therefore, research on internationalization is an interesting topic to be studied.

Related to the disclosure of Corporate Social Responsibility has been attracting the attention of Manufacturing Companies as they are most connected in international trading for either raw or finished materials. This connection also increases its complexity of companies across the nations (John et al., 2013). Hahn et al., (2013) states that the factors that influence sustainability reporting consist of: a) Determinants of internal sustainability reporting: company size and financial performance, social and environmental performance, and ownership structure. b) External determinants of sustainability reporting: company visibility, affiliated sector, country of origin, and legal requirements. In the context of Indonesia, research conducted by Gunawan (2009) shows that 'human resources' information is the most disclosed information, while 'sustainability' is the information that is least expressed in company annual reports. Documentation of information disclosed in annual reports is mostly positive and descriptive, not negative and quantitative (Gunawan, 2009). In further research, Gunawan (2014) shows that "the community" is the stakeholder group that most influences CSRD practices and "creates a positive image" is the main motivation of companies in providing CSRD. In other words, along with increasing public awareness of the impact of the company's operational activities, it indirectly changes the company's perspective to not only prioritize the interests of shareholders but also to consider the interests of stakeholders.

Based on the information above, this study aims to examine the effect of internationalization, industry type, and company size on CSR Disclosure. The expected contribution of this research is to provide empirical evidence to what extent stakeholder theory can be proven through the three factors that influence CSR Disclosure. The contributions to the science are 1) new methods used in measuring CSRD employing NVIVO Software to quantify CSRD information and 2) adding internalization instead of foreign ownership as the CSRD determinant.

\section{Literature Review}

\section{Stakeholder Theory}

Stakeholder theory emerged as a result of the development of agency theory. Stakeholder theory is embedded in management disciplines through shareholder theory revealed by Friedman (1970) and gradually developed by Freeman (1984) which combines corporate accountability to various stakeholders. Freeman (1984) focuses on views related to corporate responsibility related to various layers of stakeholders. Stakeholders are groups or individuals who can influence or be affected by the achievement of company goals, thus this implicitly indicates the sustainability of the company (going concern), among others, influenced by the behaviour and response of stakeholders to the company. These elements interact with each other and affect the company's business. In short, stakeholder theory can be defined as "groups or individuals who can influence or be influenced by the achievement of organizational goals" (Donaldson and Preston, 1995).

The company in carrying out its operations will try to adjust to the needs of stakeholders. The stronger the stakeholders, the greater the tendency for companies to adapt themselves to the needs and desires of their stakeholders (Utomo, 2000). The theory also explains that corporate goals which want to maximize profits for the shareholders interests will not be achieved if they do not pay attention to the interests of other stakeholders (Foster \& Jonker, 2005; Hawkins, 2006). Sikka (2010) explains that organizations have a moral responsibility to all stakeholders to engage in CSR activities. 


\section{Corporate Social Responsibility Disclosure (CSRD)}

The definition of CSR according to the World Business Council for Sustainable Development (WBCSD) is a business commitment in contributing to economic development through the collaboration of employees or company representatives with surrounding communities in order to create a better and quality life. Zaidi (2003) in Ambadar (2008) states that in its development CSR changed the paradigm of corporate charity, then philanthropic companies, and now corporate citizenship. Corporate charity, which is the implementation of CSR based on religious encouragement for charity; corporate philanthropy, namely the implementation of CSR which is based on encouragement derived from norms and ethics; and the latest corporate citizenship, which is CSR, which is implemented to involve in realizing social justice. There are more than 4 benefits that will be received by companies which carry out CSR activities, namely 1) increasing the company's positive image, 2) making work agreements that will help companies meet job demands from the community, 3) getting respect and appreciation from the surrounding community, and 4 ) makes the company operate safely and avoid interference from the surrounding environment. Corporate CSR activities can be seen through annual reports or corporate sustainability reporting which includes three aspects, namely economic, environmental and social, called triple bottom line reporting (Darwin, 2006).

CSR practices in Indonesia have been regulated in Law (Law) Number 40 of 2007 which regulates social and environmental responsibility. In addition to requiring CSR activities, this Law also quotes Limited Companies that are required to report on social and environmental responsibility in the annual report. The information about CSR is called as CSR Disclosure (CSRD) which widely conveys the information from company to public. In encouraging public companies in Indonesian Stock Exchange (IDX) to disclose their CSR activities, the CSR Indonesia annually conducts CSR Indonesia award in order to appreciate those who do and disclose their CSR to the community.

\section{Methods}

\section{Data Collection and Sample Selection}

The population in this study are all manufacturing sector companies listed on the Indonesia Stock Exchange (IDX) in 2013-2015. The years are selected based on GRI G3 and GRI G4 releasement years in accordance with the Verbeteen's keywords. The data used in this research is secondary data. It is data obtained indirectly by researchers through the media or other intermediaries that have been provided or collected previously by other parties. Sources of data obtained from the Thomson Reuters and Annual Reports obtained from www.idx.co.id. The analysis technique used is content analysis to obtain the value of CSRD assisted with NVIVO 11 and panel data regression analysis using the Balanced Panel Data approach with Stata 12. As shown in Table 1, the sample of this study was 372 observations.

Table 1. Sample Selection Results

\begin{tabular}{llccc}
\hline & Criteria/Limitation & \multicolumn{3}{c}{$\begin{array}{c}\text { Number of Companies } \\
\text { (period t) }\end{array}$} \\
\cline { 3 - 5 } & & 2015 & 2014 & 2013 \\
\hline $\begin{array}{l}\text { 1. Registered on the IDX as of December 31, period t } \\
\text { 2. Information limitations in audited financial statements and annual } \\
\text { reports that are published }\end{array}$ & $(20)$ & $(19)$ & $(16)$ \\
3. $\quad$ Final sample & 124 & & 124 & 124 \\
\hline & Total & & & 372 \\
\hline
\end{tabular}




\section{Definition of Variables}

\section{Dependent variables}

The dependent variable in this study is social responsibility disclosure/ CSR Disclosure (CSRD). Measurements are made with the coverage ratio of the keywords that appear in the annual report. The keywords used refer to the research of Verbeeten et al. (2016) derived from the 2013 version of the GRI framework (Table 2). The GRI guidelines cover all aspects of CSR including economic, environmental and social aspects. The distinguishment method in measuring CSRD is based on using NVIVO Software. To reduce the subjectivity, the researchers let NVIVO identify all keywords quantifying the number of references and the numbers are divided by number of pages (Verbeeten et al., 2016). We did not use the score table in measuring CSRD as many researchers did that way. Table 2 below shows keywords related to environment and social use based on Verbeeten et al. (2016) and Table 3 shows keywords based on Williams et al., (1999) and Darus et al., (2013).

Table 2. List of CSR Disclosure Keywords Verbeeten et al. (2016)

\begin{tabular}{lll}
\hline \multicolumn{1}{c}{ Environment } & & Social \\
\hline Recycled & Employment & Child labor \\
Energy Consumption & Employee turnover & Forced labor \\
Biodiversity & Collective bargaining & Compulsory labor \\
Emissions & Collective agreements & Community \\
Effluents & Occupational health & Corruption \\
Waste & Occupational safety & Public policy \\
Spills & Training & Compliance \\
Environmental impacts & Diversity & Fines \\
& Equal opportunities & Sanctions \\
& Human rights & Product responsibility \\
& Discrimination & Customer health \\
& Freedom of association & Customer safety \\
\hline
\end{tabular}

Source: Verbeteen et al. (2016)

Table 3. List of CSR Disclosure Keywords Williams et al. (1999) and Darus et al. (2013)

\begin{tabular}{|c|c|}
\hline Environment & $\begin{array}{l}\text { "General environmental considerations and statements", "Environmental policy } \\
\text { statement", "Environmental audit", "Environmental product and process-related", } \\
\text { "Environmental financially related data", "Sustainability", "Environmental } \\
\text { aesthetics", "Environmental education programs, awards and studies" }\end{array}$ \\
\hline Energy & $\begin{array}{l}\text { "Energy conversion", "Energy efficiency", "Utilization of waste materials", } \\
\text { "Recycling and associated energy savings", "Efforts to reduce energy consumption", } \\
\text { "Increasing of product efficiency", "Research on energy conservation", "Awards" }\end{array}$ \\
\hline $\begin{array}{l}\text { Human Resources and } \\
\text { Management }\end{array}$ & $\begin{array}{l}\text { "Health and safety", "Employment of } 1 \text { minorities or women", "Employee assistance, } \\
\text { remuneration and benefits", "Employee profiles", "Employee morale and relations", } \\
\text { "Industrial relations", "Employee welfare", "Employee training and conditions", } \\
\text { "Improvement of working conditions, department closures and restructuring" }\end{array}$ \\
\hline Products and Customers & $\begin{array}{l}\text { "Product development and research", "Product safety" "Product quality } \\
\text { information", "Consumer information", "Consumer satisfaction and feedback", } \\
\text { "Consumer awards', "Actions in response to consumer response" }\end{array}$ \\
\hline Community & $\begin{array}{l}\text { "Donations to community groups and charitable bodies", "Student employment", } \\
\text { "Sponsoring public health, sporting and recreational projects", "Aiding medical } \\
\text { research", "Sponsoring educational conferences, seminars or art exhibits", "Funding } \\
\text { scholarship programmes or activities", "Supporting national pride/government } \\
\text { sponsored campaigns", "Sponsoring community self-help activities", "Supporting } \\
\text { the development of local industries or community industries", "Supporting } \\
\text { community programmes and activities" }\end{array}$ \\
\hline
\end{tabular}




\section{Independent variables}

As shown in Table 3, this study uses several independent variables. Variable: Internationalization is measured by the ratio of export sales to total company sales. This proxy has been widely used in measuring internationalization (Strater, 2016). Variable: Industry Type. For research purposes, industries are grouped into two groups, namely high profile and low profile. Industry type is measured by dummy variables: 1 for high profile industries and 0 for low profile industries. Last variable: Company size is specifically measured by total assets. The rationale for using total assets as a measure of company size is that it reflects the amount of resources owned by the company.

Table 3. Variable Operational Definitions

\begin{tabular}{lll}
\hline \multicolumn{1}{c}{ Variable Type } & \multicolumn{1}{c}{ Variable Name } & \multicolumn{1}{c}{ Measurement Description } \\
\hline $\begin{array}{l}\text { Independent } \\
\text { Variable }\end{array}$ & $\begin{array}{l}\text { Industry Type (TYPE) } \\
\text { sales. }\end{array}$ & $\begin{array}{l}\text { Dummy: } 1 \text { for the high profile industry and } 0 \\
\text { for the low profile industry }\end{array}$ \\
& Company Size (SIZE) & Natural logarithm (Ln) Total Assets \\
$\begin{array}{l}\text { Dependent } \\
\text { Variable }\end{array}$ & $\begin{array}{l}\text { CSR Disclosure } \\
\text { (CSRD) }\end{array}$ & $\begin{array}{l}\text { Coverage ratio of the keywords that appear in } \\
\text { the annual report divided by number of pages. }\end{array}$ \\
\hline
\end{tabular}

\section{Theoretical Framework, Hypothesis, And Model}

Research on CSR Disclosure in Indonesia, shows that "the community" is the stakeholder group that most influences CSR Disclosure practices and "creates a positive image" is the main motivation of companies in providing CSR Disclosures. Documentation of information disclosed in annual reports is mostly positive and descriptive, not negative and quantitative (Gunawan, 2009). Multinational companies that conduct operations through international trade should be more responsive to social and environmental issues that are developing at this time. This is mainly done by companies that trade to Europe and the United States. Those internationally connected companies are indirectly requested CSR Disclosure in their annual reports by the international customers and suppliers Due to the fact that most of Indonesian Companies listed are manufacturing and have mostly connections across the nations, the researchers use this characteristic in our consideration.

The international issue we used is internationalization instead of foreign ownership since it has a mixed method (Machmud and Djakman, 2008). The variable is measured by the ratio of export sales to total company sales. This proxy has been widely used in measuring internationalization (Strater, 2016) and foreign exposure (Christiana and Martani, 2016). Based on the explanation above, the hypothesis can be formulated as follows:

H1: Internationalization has a positive effect on CSR Disclosure

In general, companies can be divided into companies with high profile and low profile companies. Companies categorized as high profile include oil and other mining companies, chemical, forest, paper, automotive, aviation, agribusiness, tobacco and cigarettes, food and beverage products, media and communication, energy (electricity), engineering, health and transportation and tourism. While the low profile industry group consists of buildings, finance, and banking, medical equipment suppliers, property, retailers, textiles and textile products, personal products, and household products (Utomo, 2000; Sembiring, 2005; Purwanto, 2011).

Manufacturing companies in Indonesia generally conduct international trade activities. Considering the characteristics of manufacturing companies that tend to have relatively large social 
and environmental impacts, especially companies categorized as high profile and conducting international trade need to express social and environmental responsibility more broadly. Previous studies which have the results of research have a significant influence on the type of industry on CSR Disclosure (Machmud and Djakman, 2008; Andreas et al., 2016). Therefore, the hypothesis can be formulated as follows.

H2: Industry type has a positive effect on CSR Disclosure

Large companies have higher political visibility and try to reduce negative impacts on the social environment (Hackston and Milne, 1996) by implementing and disclosing CSR. Previous studies which have the results of the research on the influence of company size on CSR Disclosures include Machmud and Djakman (2008); Krisna and Suhardianto (2016). The following hypothesis is formulated:

H3: Company size has a positive effect on CSR Disclosure

\section{Model Specification}

The model used to test the hypothesis of this study is:

CSRDit $=\beta_{0}+\beta_{1}($ INTER $) i t+\beta 2(T Y P E) i t+\beta_{3}(S I Z E) i t+e ;$

Where:

CSRDit $=$ Corporate Social Responsibility Disclosure, company $\mathrm{i}$ in year $\mathrm{t}$

INTER $_{\text {it }}=$ Internationalization of the company $\mathrm{i}$ in year $\mathrm{t}$

TYPE $_{i t}=$ Industrial Type: Dummy, worth 1 if the company is included in the high-profile industry and a score of 0 if the company is included in the low-profile industry

SIZE $_{i t}=$ Size of company $\mathrm{i}$ in year $\mathrm{t}$.

e $\quad=$ error

The classic assumption test, normality test, multicollinearity test, heteroscedasticity test are carried out to ensure that the regression model and each variable are feasible for hypothesis testing. The coefficient of determination test was also conducted to determine the magnitude of the effect of the independent variables on the dependent variable.

\section{Results and Discussion}

\section{Descriptive Statistics}

Descriptive statistics in Table 4 shows that the level of CSR Disclosure made by the average manufacturing company listed on the IDX is still relatively low at 0.003 . The maximum coverage ratio is obtained by PT Unilever Indonesia Tbk. in 2014 with a value of $1 \%$. The average export sales ratio is $15.8 \%$ with a maximum value of $98.27 \%$ by PT Sat Nusapersada Tbk. in 2013. A small median indicates that manufacturing companies in Indonesia still focus on domestic operations. The largest company size is PT Indah Kiat Pulp \& Paper Tbk while the smallest company size is PT Primarindo Asia Infrastructure Tbk. Based on the data below, we see that the international connection of Indonesian Manufacturing Companies is relatively low and accounted for $15.8 \%$.

Table 4. Descriptive Statistics Results

\begin{tabular}{lcccc}
\hline \multicolumn{1}{c}{ Variable } & Mean & Standard Deviation & Maximum & Minimum \\
\hline CSRD & 0.003 & 0.002 & 0.010 & 0.000 \\
INTER & 0.158 & 0.240 & 0.982 & 0.000 \\
TYPE & 0.596 & 0.491 & 1 & 0 \\
SIZE & 28.29284 & 1.585969 & 33.13405 & 24.41416 \\
\hline
\end{tabular}

CSRD: CSR Disclosure; INTER: Internationalization; TYPE: Industry type; SIZE: Company Size. 


\section{Multiple Linear Regression Results}

Prior the data was processed, the classic assumption test, normality test, multicollinearity test, heteroscedasticity test was carried out to ensure that the regression model and each variable are feasible for hypothesis testing. The normality test supports asking whether the residue has a normal distribution (Gujarati and Porter, 2010). Normality test is used to determine whether the variables used in the model are normally distributed so that the residuals are also normally distributed. To get normally distributed variables, outlier data handling is needed.

Testing is done by looking at the slope or slope of each variable. If the variable has a slope or slope exceeds the threshold of -3 and 3 then a winsorizing treatment was performed to adjust the outlier data with the specified maximum and minimum values. The other classical assumptions were carried based on its requirements. The Researchers conducted a Hausman Test indicating the use of the Random Effect Model in testing the regression model. The coefficient of determination test was also conducted to determine the magnitude of the effect of the independent variables on the dependent variable. The regression result is shown in Table 5.

Table 5. Regression Results Factors Affecting CSR Disclosures

\begin{tabular}{|c|c|c|c|}
\hline \multicolumn{4}{|c|}{ CSRDit $=\beta_{0}+\beta_{1}$ INTERit $+\beta_{2}$ TYPEit $+\beta_{3}$ SIZEit $+e$} \\
\hline Variable & Prediction & Coefficient & Prob \\
\hline CSRD & & -0.0042801 & $0,063 *$ \\
\hline INTER & $+(\mathrm{H} 1)$ & -0.0004351 & 0.410 \\
\hline TYPE & $+(\mathrm{H} 2)$ & -0.0001492 & 0.574 \\
\hline SIZE & $+(\mathrm{H} 3)$ & 0.0002839 & $0.001 * * *$ \\
\hline $\mathrm{N}$ & & & 372 \\
\hline Adjusted $\mathrm{R}^{2}$ & & & 0.0495 \\
\hline Prob & & & $0.0062 * * *$ \\
\hline $\begin{array}{l}\text { CSRD: Disc } \\
\text { SIZE: Compa } \\
* * * \text { significar } \\
* * \text { significant } \\
* \text { significant }\end{array}$ & $\begin{array}{l}\text { CSR; INT } \\
\text { e. } \\
\text { el } \alpha=1 \% \\
\alpha=5 \% \\
\alpha=10 \%\end{array}$ & $\begin{array}{l}\text { ternationaliza } \\
\text { iiled test) } \\
\text { led test) } \\
\text { led test) }\end{array}$ & YPE: Industry Type; \\
\hline
\end{tabular}

\section{The Effect of Internationalization on Corporate Social Responsibility Disclosure}

The results in Table 5 show that internationalization has no effect on CSR Disclosure. Thus, Hypothesis 1 is not supported. The results have not been able to prove stakeholder theory which states that the going concern of a company is influenced by the behavior and response of stakeholders to the company. The company in carrying out its operations will try to adjust to the needs of stakeholders. The stronger the stakeholders, the greater the tendency for companies to adapt themselves to the needs and desires of their stakeholders (Utomo, 2000).

This might be due to the fact that Indonesian companies seem to be still focusing on their domestic operations, because the average proportion of the company's export sales compared to total sales is relatively low. This low export value is influenced by external factors such as government policies, social and cultural conditions and politics and internal factors such as company characteristics and strategies (Anas et al., 2005). In addition, to date no trade barriers have been imposed on the products of manufacturing companies. Looking at CSR theory, for Indonesian companies seem not to put internationalization as its driver in providing such CSR Disclosure since that information is mostly required by the Indonesian Law No 40 (2007) rather than foreign demands. 


\section{Effect of Industry Type on Corporate Social Responsibility Disclosure}

Hypothesis 2 is not supported. Table 5 shows that the type of industry does not affect the disclosure of corporate social responsibility. This result also cannot prove stakeholder theory. According to Utama (2010), in addition to the absence of public awareness of the importance of CSR, the weak public pressure on companies to carry out CSR may be due to lack of information about the social and environmental impacts of company activities caused by their limited access to CSR reports. Companies that write CSR reports will only provide good information in their reports. Gunawan (2014) also shows "creating a positive image" is the main motivation of companies in providing CSR Disclosures.

\section{Effect of Company Size on Corporate Social Responsibility Disclosure}

Table 5 shows that company size affects the disclosure of corporate social responsibility. These results support Hypothesis 3. This study is in line with research by Machmud and Djakman (2008); Krisna and Suhardianto (2016). Large companies have higher political visibility and try to reduce negative impacts on the social environment (Hackston and Milne, 1996) by implementing and disclosing CSR. The implementation of social responsibility can also be used as a medium to maintain the company's reputation. Given that large companies get more attention from stakeholders, therefore this company will try to be more obedient and try as little as possible to have a negative influence on society and the environment. The implementation of CSR will then be disclosed in the company's reporting activities. Large companies have the resources to express corporate social responsibility more broadly and comprehensively.

\section{Conclusion}

In this study, company size is proven to have an influence on CSR Disclosure. This shows that the larger the company will have the ability to express social and environmental responsibility more broadly and comprehensively. Large companies have higher visibility and seek to reduce negative environmental and social impacts. The implementation of social responsibility can also be used as a medium to maintain the company's reputation. In addition, large companies are influenced by the behaviour and response of stakeholders to more companies.

This study failed to prove the effect of internationalization and industry type on CSR Disclosure. Thus, research has not been able to prove stakeholder theory and CSR theory. Internationalization is not strong enough to influence CSR Disclosure. This fact is probably caused by the small export sales of Indonesian manufacturing companies which seem to still focus on their domestic operations. In addition there has been no pressure on Indonesia's manufactured export products from overseas stakeholders. Industry type does not affect CSR Disclosure. Weak community pressure on companies to carry out CSR may be due to lack of information about social and environmental impacts of company activities caused by their limited access to CSR Reports. Companies reporting CSR will only provide good information in their reports.

This research has implications for stakeholders, especially the public, to put more pressure on companies in implementing and expressing social responsibility, especially those in the highprofile industry, because they have a greater impact. For the government, it should encourage companies that carry out internationalization to carry out and express social responsibility more broadly. The global pressure on the implementation of sustainability issues and tend to be non-tariff barriers have a significant impact on the company. Before the pressure from the international community is given to the industry, sustainability issues should be the company's main concern.

This study has several limitations. First, the internationalization measurement only uses the ratio of overseas sales divided by total sales. Further research measurement can be expanded through foreign exposure. Second, the sample is limited to manufacturing companies in Indonesia during 2013-2015. Further research can expand the observation of companies from other industries, 
The effect of internationalization, industrial type, and company size on corporate social responsibility disclosure

especially the agricultural industry affected by the decision of palm resolution by the European Union. Third, the measurement of CSR Disclosure refers to Verbeteen et al. (2016), Williams et al. (1999), and Darus et al. (2013) by looking at the percentage of coverage of certain words or phrases in the annual reports. Future studies can expand measurements through keywords by the GRI.

\section{References}

Ambadar, J. (2008). CSR dalam Praktik di Indonesia. Jakarta: PT. Elex Media Komputindo

Andreas et al. (2016). Determinants of Corporate Social Responsibility Disclosure and Investor Reaction. International Journal of Economics and Financial Issues, 6(S4) 11-17.

Anas, A., Herri, Karimi S. (2005). Analisa Faktor-Faktor Perusahaan Yang Mempengaruhi Kinerja Ekspor (Studi Kasus Perusahaan Ekspor Di Sumatera Barat). Jurnal Bisnis dan Manajemen Vol. 1 No. 1.

Cahyono, Budi. (2011). Pengaruh Corporate Social Responsibility Terhadap Kinerja Perusahaan dengan Kepemilikan Asing sebagai Variabel Moderating (Studi Empiris pada Perusahaan Manufaktur yang terdaftar di Bursa Efek Indonesia), Universitas Diponegoro, Semarang.

Christiana dan Martani. (2016). Determinan Praktik Thin Capitalization Listed Companies Di Indonesia 2010-2013. The Article published in Konferensi Regional Akuntansi III (KRA III) Universitas Jember, 20 to 21 April 2016.

Darus, Faizah, Engku Artini, dan Haslindah Yusoff. (2013). "CSR Web Reporting: the influence of Ownership Structure and Mimetic Isomorphism". Procedia Economcis and Finance. 7. 236242.

Donaldson, Thomas and Lee E. Preston. 1995. The Stakeholder Theory of the Corporation: Concepts, Evidence, and Implications. Academy of Management Review, Vol. 20, No. 1, Pages $65-91$.

Freeman, R. Edward. 1984. Strategic Management: A Stakeholder Approach. Pitman: London.

Friedman, Milton. 1970. The Social Responsibility of Business Is to Increase Its Profits. New York Times Magazine, September 13, 1970.

Gujarati, Damodar N. Dawn C. Porter. (2010). Basic Econometrica. Fifth Edition. New York: Mc Graw Hill

Gunawan, J., Djajadikerta, H.G. and Smith, M. (2009). An examination of corporate social disclosures in the annual reports of Indonesian listed companies. Asia Pacific Centre for Environmental Accountability Journal, Vol. 15 No. 1, pp. 13-36.

Gunawan, Juniati. (2015). Corporate social disclosures in Indonesia: stakeholders' influence and motivation. Social Responsibility Journal, Vol. 11 Issue: 3, pp.535-552.

Hahn at al., (2013). Determinants of sustainability reporting: a review of results, trends, theory, and opportunities in an expanding field of research. Journal of Cleaner Production. 59: 5 - 21.

John, E.A., John, A.O., \& Adedayo, O.E. (2013). Corporate social responsibility and financial performance: Evidence from nigerian manufacturing sector. Asian Journal of Management Research, 4(1), 153-162.

Krisna, Aditya Dharmawan dan Novrys Suhardianto. (2016). Faktor-faktor yang mempengaruhi Pengungkapan Tanggung Jawab Sosial. Jurnal Akuntansi dan Keuangan, Vol. 18, No. 2, November 2016, 119-128. 
Loh, L., Thao, N.T., Sim, I., Thomas, T., \& Yu, W. (2016). Sustainability Reporting in Asean: State of Progress in Indonesia, Malaysia, Singapore and Thailand 2015. Singapore: Centre for Governance, Institutions and Organisations (CGIO) at NUS Business.

Machmud, Novita dan Djakman, Chaerul D. (2008). Pengaruh Struktur Kepemilikan terhadap Luas Pengungkapan Tanggung Jawab Sosial (CSR Disclosure) pada Laporan Tahunan Perusahaan: Studi Empiris pada Perusahaan Publik yang Tercatat di Bursa Efek Indonesia tahun 2006 . Simposium Nasional Akuntansi XI Pontianak 2008.

Moon, J., \& Chapple, W. (2005). Corporate social responsibility (CSR) in Asia a seven-country study of CSR Web Site Reporting. Business and Society, ,44(4), 415-441

Purwanto, Agus. (2011). Pengaruh Tipe Industri, Ukuran Perusahaan, Profitabilitas, Terhadap Corporate Social Responsibility. Jurnal Akuntansi \& Auditing 13 Volume 8/No. 1/November 2011: $1-94$

Sembiring, Eddy Rismanda. (2005). Karakteristik Perusahaan dan Pengungkapan Tanggung Jawab Sosial: Studi Empiris pada Perusahaan yang Tercatat di Bursa Efek Jakarta. Simposium Nasional Akuntansi 8. Solo. 15-16 September 2005.

Sträter, W.B. (2016). The moderating effect of internationalization on the relationship between CSR and tax avoidance. Thesis. University of Groningen.

Utama, Sidharta. (2011). An evaluation of support infrastructures for corporate responsibility reporting in Indonesia. Asian Business Management 10: 405.

Utomo, M Muslim. (2000). "Praktek Pengungkapan Sosial pada Laporan Tahunan Perusahaan di Indonesia (Studi Perbandingan antara Perusahaan-Perusahaan High Profile dan Low Profile)". Simposium Nasional Akuntansi III.

Verbeteen et al. (2016). "Are CSR Disclosures Relevant for Investors? Empirical Evidence from Germany”. Management Decision, 54(6), 1359-1382.

Williams, S. M., Pei, C.-A. H. W., 1999. Corporate Social Disclosures by Listed Companies on Their Web Pages: An International Comparison. The International Journal of Accounting 34(3), p. 389

Yoga, Sukmana. (2017). Soal Sawit, Pemerintah Sebut Tudingan Parlemen Uni Eropa Mengada-ada. $\begin{array}{lllll}\text { Accessed } & \text { On } & \text { Mei } & 17, & \text { from }\end{array}$ http://bisniskeuangan.kompas.com/read/2017/04/10/191037026/soal.sawit.pemerintah.sebu t.tudingan.parlemen.uni.eropa.mengada-ada 